\title{
The Impact of The Rural Culture and Cultural Attractions on Poverty Alleviation: The Moderating Effect of Tourism Resources
}

Komathi Wasudawan, Mahani Mohammad Abdu Shakur \& Rossazana AbRahim

To Link this Article: http://dx.doi.org/10.6007/IJARBSS/v11-i1/8546

DOI:10.6007/IJARBSS/v11-i1/8546

Received: 12 December 2020, Revised: 02 January 2021, Accepted: 17 January 2021

Published Online: 31 January 2021

In-Text Citation: (Wasudawan at el, 2021)

To Cite this Article: Wasudawan, K., Abdu Shakur, M. M., \& Ab-Rahim, R. (2021). The Impact of The Rural Culture and Cultural Attractions on Poverty Alleviation: The Moderating Effect of Tourism Resources. International Journal of Academic Research in Business and Social Sciences, 11(1), 595-614.

Copyright: (C) 2021 The Author(s)

Published by Human Resource Management Academic Research Society (www.hrmars.com)

This article is published under the Creative Commons Attribution (CC BY 4.0) license. Anyone may reproduce, distribute, translate and create derivative works of this article (for both commercial and non-commercial purposes), subject to full attribution to the original publication and authors. The full terms of this license may be seen at: http://creativecommons.org/licences/by/4.0/legalcode

Vol. 11, No. 1, 2021, Pg. 595 - 614

Full Terms \& Conditions of access and use can be found at http://hrmars.com/index.php/pages/detail/publication-ethics 


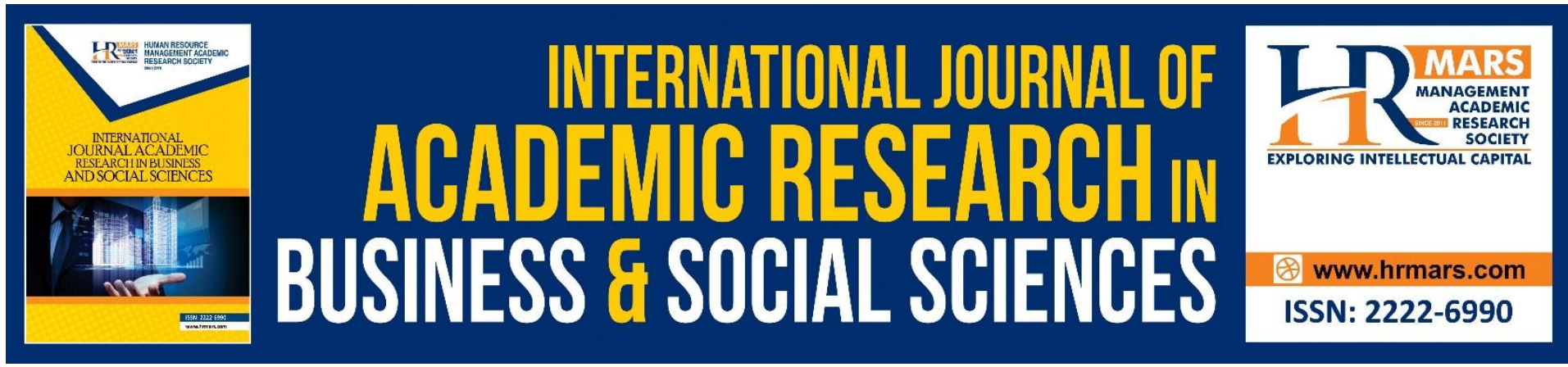

\title{
The Impact of The Rural Culture and Cultural Attractions on Poverty Alleviation: The Moderating Effect of Tourism Resources
}

\author{
Komathi Wasudawan, Mahani Mohammad Abdu Shakur \& \\ Rossazana Ab-Rahim \\ Swinburne University of Technology, Sarawak, Malaysia, Universiti Malaysia Sarawak, \\ Sarawak, Malaysia. \\ Email: KWasudawan@swinburne.edu.my
}

\begin{abstract}
This study aims to investigate the impact of rural culture and cultural attractions on poverty alleviation and the moderating effect of tourism resources on rural, culture, wildlife, nature and physical. Convenience sampling was applied in selecting 520 respondents. The Statistical Package for Social Science was used to analyse the descriptive statistic while Partial Least Square-Structural Equation Modelling (SEM) was used to analyse the hypotheses. The results show both rural culture and cultural attractions have a positive effect on poverty alleviation. Besides, tourism resources have a positive moderating effect on rural culture and poverty alleviation. Poverty reduction through tourism, communities right to use tourism resources and accommodate different cultural views are supported by Human Development Theory on the positive findings. However, tourism resources a negative result on cultural attractions and poverty alleviation. Therefore, this study suggests that preserving cultural attractions such as cultural buildings, landscapes, monuments, traditions, arts, crafts, food, and customs should be encouraged for socio-economic benefits.
\end{abstract}

Keywords: Rural Culture, Cultural Attractions, Tourism Development, Moderator, Tourism Resources, Malaysia

\section{Introduction}

Cultural tourism is defined as an interaction between tourists and locals in exchanging the different ways of life that has been practiced from generation to generation (Dong 2020). Cultural tourism is a product that contributes economic and non-economic benefits to people (Mitchell \& Ashley, 2010). Moreover, cultural tourism fosters pride through the sharing of traditional and customary values and helps in preserving culture (Satarat, 2010). In Sarawak, the cultural values, heritage, and traditions of 28 ethnic groups provide an avenue to promote cultural tourism (Ministry of Tourism, Arts, and Culture Sarawak, 2016). The ethnic groups' traditional knowledge of the forest and medicinal plants, fishing activities, weaving techniques, cultural heritage, and festivals have also contributed to cultural tourism (Lo, Ramayah \& Hui 2014). 
In developing countries, economic diversification has contributed economically and culturally to the livelihood of local communities (Manwa \& Manwa, 2014). Sarawak receives tourists from Brunei, Indonesia, the Philipines, China, Singapore, the United Kingdom, India, Australia, and Thailand. Sarawak's Gross Domestic Product from tourism increased from RM8.4 Billion in 2016 to RM8.59 Billion in the following year. Global tourism is projected to attract 1.8 billion tourists in 2030 (United Nations World Tourism Organization, 2017). The projection shows the potential domestic and inbound overnight in hotels lead a country to conclude that tourism alleviates poverty (Llorca-Rodríguez, García-Fernández \& Casas-Jurado, 2020). In 2016, Sarawak (1.7\%) had the smallest Income Recipients Per household compared to Labuan $(2.0 \%)$ that had the highest among all the states in Malaysia. The Mean Household Income by working population in Sarawak had the smallest increase at $1.3 \%$ than $19 \%$ on Penang Island. Less than $6 \%-20 \%$ of households in rural areas of Sarawak located within $5 \mathrm{~km}$ - $9 \mathrm{~km}$ to the government secondary schools, and public healthcare and only $30 \%$ of households in Sarawak have access to piped water (Khazanah Research Institute, 2018).

Success in tourism has created a mechanism for engaging the local community in tourism and utilizing tourism resources that contribute toward socio-economic development (Pawson, d'Arcy \& Richardson, 2015). Therefore, based on current tourism Gross Domestic Product trends, Sarawak provides the best avenue for this study to embark upon the issue of the tourism sector and its contribution to human development. Specifically, this study examines the impact of rural culture and cultural attractions on poverty alleviation and to identify the moderating effect of tourism resources on poverty alleviation.

\section{Literature Review}

The homestay programme emphasised in the Ninth Malaysia Plan (2006-2010) through the Rural Community Tourism Program and the Homestay Tourism Program focused on promoting the rural culture in Malay villages to protect, preserve, and enhance Malay traditions (Economic Planning Unit, 2006; Satarat, 2010). Like, the homestay programme, community-based tourism such as in Namibia (Saarinen 2010), Thailand (Satarat, 2010; Nitikasetsoontorn, 2014), Malaysia (Lo, Ramayah \& Hui, 2014), and community-based cultural tourism (Salazar, 2012) have introduced rural culture to tourists. Rural culture plays an essential role in developing tourism products to generate income. Therefore, rural culture was chosen as an independent variable in this study.

Cultural attractions is identified as the movement of a person for cultural enthusiasm, such as the performing arts (e.g., the Adelaide Arts Festival or Perth International Arts Festival), cultural tours (e.g., to museums, temples, historical monuments or archaeological sites), pilgrimage tours (e.g., religious travel), festival tours (e.g., Jazz festivals or Food festivals) (Derrett, 2004). Local food festivals have been identified as a cultural attractions in Italy, Australia, Malaysia, and New Zealand discouraged the growth of fast food industries and created job opportunities for the farmers (Frost \& Laing, 2013). Jazz festivals (e.g., Jazzinty Novo Mesto and Jazz Cerkno) in the Republic of Slovenia increased tourist arrivals and employment in local areas (Vecco \& Srakar, 2017). Cultural attractions in a few countries have added value to tourism jobs and economic growth; therefore this study further measures cultural attractions in alleviating poverty in Sarawak. 
Tourism as a labour-intensive business uses tourism resources owned by the local community or the government to enhance the local community's livelihood and a country's economy (Keovilay, 2012; Miyakuni, 2012; Truong, 2014; Njoya \& Seetaram, 2018). Tourism resources are unique because consumption happens at the place of production. The scenario created at tourist destinations is more likely to have a direct impact than other places where product consumption is located away from it's destination (Duffield, 1982). The development of tourism resources brings monetary and non-monetary benefits to the community by operating those tourism resources (Gholami, Assayesh \& Alipour-Nakhi, 2010). Sarawak blessed with tourism resources which have earned benefits for the local people with the use of tourism resources. Tourists travel to experience tourism resources in different places, while the local community uses tourism resources to earn a living (Sathkumara, 2014). In this study, cultural, wildlife, natural, rural, and physical (e.g., caves) resources are categorised as tourism resources and measured as a formative moderator variable.

On the contrary, the absence of local government involvement and lack of community knowledge in Vietnam has discouraged the local community from employing cultural resources in tourism (Suntikul et al., 2016). The Himalayan community in Bhutan has embraced the Gross National Happiness rather than the Gross National Product in measuring the quality of life. The Gross National Happiness measures happiness, spirituality, and cultural authenticity. Cultural authenticity is among the most popular attractions for tourists. As a result, cultural resources have impressively increased the number of tourist arrivals in Bhutan and alleviated poverty (Suntikul \& Dorji, 2016).

Wildlife tourism is growing in protected areas in developing countries that are rich in biodiversity and rainforests. The Volcanoes National Park Rwanda is famous for mountain gorillas. The National Park contributes to the pro-poor income through value chain businesses, namely, accommodation, food and beverages, gorilla trekking tourism activities, and shopping (Spenceley et al., 2010). In North America, wild horses' tourism contributes to economic development. Tourists tend to hug the wild horses as hugging symbolises the western frontier (Notzke. 2016). While, wildlife resources contribute to a country's economy, employing wildlife resources in tourism interrupts the ecology of the animals such as disturbance in feeding and breeding patterns, interruption of parent and offspring bonds, and habitat modification (Moorhouse, d'Cruze \& Macdonald, 2017). Therefore, employing wildlife resources such as Orangutan, Hornbill, Crocodile, Wild Boar and Proboscis Monkey as tourism resources to generate income is acceptable through conservation and protection of ecology strategies in Sarawak.

Ban Mae village, in Chiang Mai, Thailand utilises the natural resource of wild orchids as a tourism product and a symbol of the village's attractions. The local community sells the wild orchids and wild honey to tourists. In Bang Chao Cha village, Angthong, Thailand, the local community sells baskets made from rattan (Satarat, 2010). Rural resources are defined as capital assets to generate income via tourism (Chin, 2015). In Western countries, visiting vineyards, wineries, wine demonstrations, and wine festivals are considered as utilising rural resources (Hall \& Macionis, 1998). In the Waterloo region of Ontario, Canada, the rural landscape such as rolling hills, maple woods, and the Grand River Valley are used to produce rural tourism products (McClinchey \& Carmichael, 2010). In Sarawak, rural tourism, sustainable rural tourism, village tourism, rural sports tourism (e.g., folk games), farm 
tourism, geo-tourism, country music (e.g., sape), rural medical tourism (e.g., herbs) and gastronomy tourism (food tourism) can be created with the use of rural resources to generate income.

Physical resources encompass caves, heritage buildings, landmarks, historical places, memorials, and museums (Kiernan, 2013). Physical resources generate income from entrance fees (Butler \& Hinch, 2007). Caves create national parks for ecosystem sustainability through tourism (Gray, 2004; Kiernan, 2013). The Musanze Caves in Rwanda uses its physical resources to promote archaeology, nature, adventure, heritage, and cultural tourism. Tourism in Hong Kong contributes to conserving physical heritage buildings. Using physical heritage buildings in tourism extends the building's life span, saves demolition waste, encourages energy reuse, and provides economic benefits to the locals (Yung \& Chan, 2012).

Employing tourism resources of culture, wildlife, nature and rural and physical resources brings socio-economic improvement to people. Therefore, in this study, tourism resources are identified as a moderator because when tourism resources are utilised, the impacts of rural culture and cultural attractions increase and thus the poverty level decreases. Tourism resources as a moderator measure the strength and/or weakness relationship between rural culture, cultural attractions, and poverty alleviation (Baron \& Kenny, 1986).

Poverty alleviation means improving human development by having earnings above the Poverty Line Income, raising the socio-economic status of an individual and improving access to sources of energy, water supply, tarred roads, cooking appliances, education and healthcare (Manwa \& Manwa, 2014). As poverty declines, the income of a household increases with a person's ability to earn more cash. An increase in income improves the quality of life and social welfare for the household (Sen, 1999). Additionally, developing countries give importance to poverty alleviation to people living in extreme poverty and living on earnings of less than US\$1.90 per person per day (World Bank, 2016). Therefore, poverty alleviation was chosen as an dependent variable in this study.

\section{Underpinning Theory}

In 1990 s to 2000s, the Human Development Theory was used to alleviate poverty through tourism, to increase community access to tourism resources and to accommodate different cultural views (Welzel, Inglehart \& Klingemann, 2003; Saarinen \& Rogerson, 2014; Sharpley \& Harrison, 2019). The Human Development Theory in tourism started with pro-poor tourism, philanthropy tourism and volunteer tourism in British and Europe, then expanded to Australia, the United States and is now growing in Asian and African countries as charity tourism that works to alleviate poverty (Zyl, Inversini \& Rega, 2015). Pro-poor tourism, philanthropy tourism and volunteer tourism carry the concept of traveling for humanitarianism to improve the quality of life among the local community and preserve the culture (Mostafanezhad, 2014; Sharpley \& Harrison, 2019). The theory integrates poverty reduction strategies to recognise the multi-dimensional nature of poverty such as a lack of electricity, clean drinking water, infrastructure, education, and healthcare and believed tourism revenue benefits the locals via cultural tourism (Sharpley \& Telfer, 2014). 


\section{Conceptual Framework}

This study investigates the effects of rural culture and cultural attractions on poverty alleviation and examines the relationship of the rural culture and cultural attractions with tourism resources on poverty alleviation. The rural culture (Satarat, 2010; Saarinen, 2010; Salazar, 2012; Nitikasetsoontorn, 2014), cultural attractions (Frost \& Laing, 2013; Vecco \& Srakar, 2017); tourism resources (Mthembu, 2011; Keovilay, 2012; Miyakuni, 2012; Truong, 2014) and poverty alleviation (World Bank, 2016) have been adopted from various studies. In short, this study aims to investigate tourism resources as a formative moderator between rural culture, cultural attractions, and poverty alleviation and contribute to the research gap as shown in Figure 1.

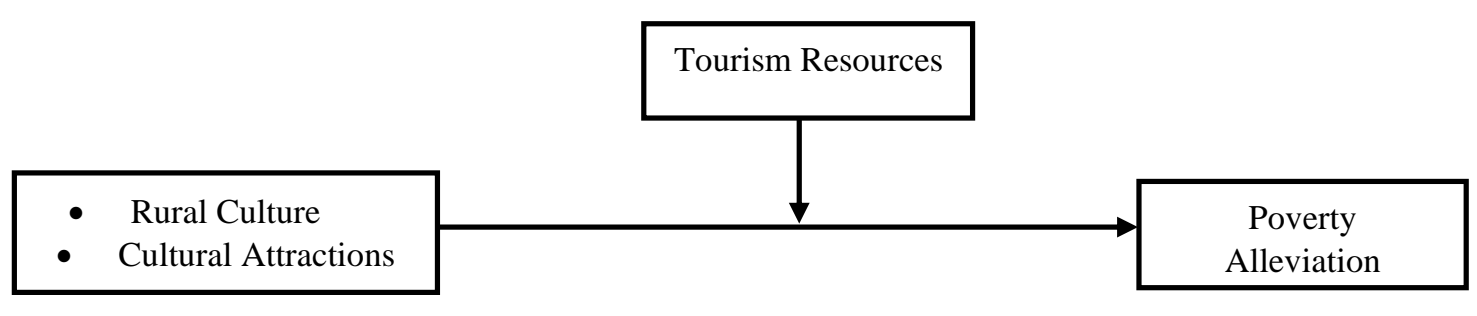

Figure 1: The conceptual framework

Source: Satarat (2010), Saarinen (2010), Mthembu (2011), Keovilay (2012), Miyakuni (2012), Salazar (2012), Frost and Laing (2013), Nitikasetsoontorn (2014), Truong (2014), World Bank (2016), and Vecco and Srakar (2017)

\section{Rural Culture and Poverty Alleviation}

Rural culture and poverty alleviation are related to homestay programmes or communitybased tourism. Homestay or community-based tourism is an alternative form of lodging in place of expensive accommodation (Agyeiwaah, Akyeampong \& Amenumey, 2013). Homestays allow tourists to stay with a selected accommodation provider and experience the host's daily lifestyle and rural culture, which in turn increases the involvement of rural communities to generate income (Ahmad, Jabeen \& Khan, 2014). The homestay acivities in Johor, Malaysia have brought a positive impact for a better source of livelihood (Salleh et al., 2016). A community-based tourism weaving co-op project in Ccaccaccollo, Peru has created employment and income from the selling of the woven products to tourists (Lucchetti \& Font, 2013). Another study on community-based tourism and poverty alleviation in Sapa, Vietnam highlights that 55 communities were glad about the income generation through communitybased tourism (Le, Weaver \& Lawton, 2016). Overall, rural culture increases tourist arrivals and improves life for the local communities. Hence, hypothesis $\mathrm{H} 1$ is structured:

H1: There is a positive relationship between rural culture and poverty alleviation.

\section{Cultural Attractions and Poverty Alleviation}

Tourists often demand an authentic exhibition of culture and lifestyles that are considerably different from one another (Reisinger \& Steiner, 2006). Therefore, cultural attractions are a great potential for travel itineraries. People with different lifestyles, traditions and cultural patterns offer different customs, dress codes, handicrafts, ways of cooking and ways of producing local food. The differentiation in culture creates a unique attractions for tourists (Cetin \& Bilgihan, 2016). At the same time, the local communities' involvement in providing cultural activities for tourism directly promotes a destination as a cultural attractions 
(Richards, 2001). Thus, cultural attractions are one of the suitable mechanisms to bring local communities all over the world out from poverty (Aslam \& Jolliffe, 2015). For example, in the Republic of Slovenia, the Jazz Festival as a cultural attractions increased tourist arrivals and alleviated poverty (Vecco \& Srakar, 2017). Cultural attractions also enable the local communities to earn from selling entrance tickets and souvenirs, and working as tour guides (Ertugral \& Dincer, 2003). Generally, the tourism sector promotes the selling of traditions and exotic lifestyles as a cultural attractions. Hence, hypothesis $\mathrm{H} 2$ is structured:

H2: There is a positive relationship between cultural attractions and poverty alleviation.

\section{Tourism Resources Moderate the Relationship between Rural Culture and Poverty Alleviation}

As many local communities continue to battle with poverty, tourism in the global trade represents people to travel to experience diverse tourism resources which contributes to poverty alleviation (Muhanna, 2007). Tourism resources bring tourists in as consumers get in contact with the local communities who are as a producers of tourism resources which generate socio-economic benefits (Musinguzi, 2012). One of the tourism resources that is often abundant in local communities is cultural resources in rural areas. Tourism provides a path to market the cultural resources through cultural tourism and homestays (Okumus et al., 2012). Cultural preservation in Human Development Theory has also created an awareness among the younger generation of non-financial benefits (Hillman, Moyle \& Weiler, 2017). Rural culture acts as an effective tool in fighting against poverty especially with the use of tourism resources (Musinguzi, 2012). Therefore, H3 is developed:

H3: Tourism resources moderate the relationship between rural culture and poverty alleviation.

\section{Tourism Resources Moderate the Relationship between Cultural Attractions and Poverty Alleviation}

Tourism resources as in physical heritage buildings, historical places, landmarks, museum, craft applications, cultural landscapes, local traditional food, clothing and festivals symbolise the differences in people's lifestyle as cultural attractions (Smith \& Ram, 2017). Therefore, cultural attractions produce various types of tourism products such as arts tourism, religious tourism, pilgrim tourism, indigenous cultural tourism, ethical tourism, community-based tourism, wine tourism, heritage tourism for the world's population to sightsee. Moreover, tourism resources are also treated as livelihood resources in the context of achieving community development (Daskon \& Binns, 2010). Cultural attractions involve the local communities in tourism while creating permanent solutions to poverty by generating financial benefits (Kennedy \& Dornan, 2009). Viewing tourism resources as a livelihood resource is also explained in the sustainable livelihood framework (Petersen \& Pedersen, 2010). Thus, the moderator of tourism resources has a stronger effect on cultural attractions and poverty alleviation. Therefore, $\mathrm{H} 4$ is developed:

H4: Tourism resources moderate the relationship between cultural attractions and poverty alleviation.

\section{Research Method}

Kuching and Miri were selected for this study as both divisions record the highest tourist arrivals among other divisions in Sarawak. Tourist arrival in the year 2016 stands at 815,497 in Kuching followed by 352,888 in Miri (Ministry of Tourism, Arts, and Culture Sarawak, 2016). 
Sampling gives a reliable sample size as well as saves time and cost rather than collecting data from an entire population (Rattan Eagles \& Mair, 2012). A simplified formula by Yamane (1967) was used to calculate the sample size, where a 95\% confidence level and the level of precision at 0.05 is assumed. In 2016, Kuching the capital of Sarawak had has the highest population with 771,600 followed by Miri with 380,600 . So, the total population of Kuching and Miri Divisions was 1,152,200.

$$
\begin{aligned}
& \mathrm{n}=\frac{N}{1+N(e)^{2}} \\
& \mathrm{n}=\frac{1,152,200}{1+1,152,200(0.05)^{2}}=400 \text { respondents }
\end{aligned}
$$

Where:

$\mathrm{n}=$ sample size

$\mathrm{N}=$ population size

$\mathrm{e}=$ level of precision

Yamane's (1967) sample size formula suggests that the number of 400 respondents is adequate. In addition, Israel (1992) recommends that an adjustment in the sample size is needed to compensate for non-response to the questionnaires. Many researchers commonly add $10 \%-30 \%$ to the sample size to compensate for uncompleted, unfilled and unreturned questionnaires. However, in this study the researcher included an additional $70 \%$ for mailed questionnaires. The number of mailed questionnaires can be substantially larger than the number required for a desired level of confidence and precision (Israel, 1992). In this study the sample size was increased by $70 \%$ from 400 , with an additional 280 giving a sample size of 680. A sample size sum of between 30 - 500 is sufficient for most studies (Sekaran. 2003).

$400 *(70 / 100)=280$ respondents

$400+280=680$ total respondents

The data collected was quantitative primary data. Removing the uncompleted, unfilled, and unreturned questionnaires, the remaining 520 questionnaires were used to analyse the impact of tourism on poverty alleviation. Convenience sampling was used to select the employees from the Sarawak Cultural Village (68 respondents), hotels [e.g., United Yes Retreat; Miri Merit; Miri Park City; Miri Marriot and Mulu-Marriot (163 respondents)], hostel [e.g., Bunker bed and breakfast (1 respondent)], resorts [e.g., Damai Puri; Damai Beach; Palm Beach and The Nomad (34 respondents)], national parks [e.g., Jong's Crocodile Park; Samajaya; Semenggoh Nature Reserve; Kubah; Santubung; Mount Gading and Mulu National Parks and Niah, Fairy and Wind Caves (164 respondents)], Malaysian Handicraft Development Corporation, Sarawak Branch (24 respondents) souvenir shops [e.g., Sue J's Handicraft, My Village Barok, Sarawak Handicraft, Usun Souvenir, and Art and Souvenir Gallery (8 respondents)], and Layer Cake Houses [e.g., Warisan Layer Cake House and Mira Layer Cake Factory (11 respondents)], as well as homestay owners [e.g., Annah Rais; Santubong; Tanah Hitam; Pueh; Kedayan and Patrick Homestays (47 respondents)]. 
The questionnaire has two sections. The first section covers, the profile of respondents while the second the Likert scale questions. The Likert-scale questions used a 1-5 and 1-7 scale from 'strongly disagree' to 'strongly agree' to measure 34 items. The 7-point Likert scale was used to measure the dependent variable of poverty alleviation, while the 5-point Likert scale was used to measure the independent variable of rural culture, cultural attractions, and tourism resources. The variety of choices in the scales created more variance among the variables (Bruner \& Hensel, 1993). The items used to measure poverty alleviation, rural culture, cultural attractions, and tourism resources were adapted from Faulkner and Tideswell (1997), Yoon, Gursoy and Chen (2001), Satarat (2010), Mthembu (2011), Keovilay (2012), Musinguzi (2012), Miyakuni (2012), Mohamed (2013), Truong (2014), and Nitikasetsoontorn (2014).

The questionnaires were hand-delivered to the Sarawak Cultural Village, accommodation providers, National Parks, souvenir shops, and Layer Cake Houses. The respondents were requested to fill the questionnaire at their convenience within a week upon delivery. Respondents who failed to fill in the questionnaires within a week were given another week's extension; after the deadline, the questionnaires were considered unfilled. The Statistical Package for Social Science version 22.0 was used to describe the demographic characteristics of the respondents, while Partial Least Squares-Structural Equation Modelling 3.0 was utilized to assess the measurement and structural models. Partial Least SquaresStructural Equation Modelling 3.0 was employed because the model involved a combination of formative and reflective items (Hair, Ringle \& Sarstedt, 2011). The items on tourism resources were formative, while those on rural culture, cultural attractions, and poverty alleviation were reflective.

\section{Results}

\section{Descriptive Analysis}

Most of the respondents in this study were male (56.5\%), aged between 18-62, of Malay ethnicity (27.3\%), married (64.1\%) and with secondary education (65.6\%). The majority of the respondent earns between RM1001-RM1500. (see Table 1). 
Table 1: Demographic characteristics of the respondents

\begin{tabular}{|c|c|c|c|c|c|}
\hline \multirow[b]{2}{*}{$\begin{array}{l}\text { Demographi } \\
\text { c }\end{array}$} & \multirow[b]{2}{*}{$\begin{array}{l}\text { Frequency } \\
\quad(n)\end{array}$} & \multirow[b]{2}{*}{$\begin{array}{c}\text { Percentage } \\
(\%)\end{array}$} & \multirow[b]{2}{*}{ Demographic } & \multicolumn{2}{|c|}{ Respondents $(N=520)$} \\
\hline & & & & Frequency $(n)$ & $\begin{array}{l}\text { Percentage } \\
\text { (\%) }\end{array}$ \\
\hline Gender & & & Education status & & \\
\hline Male & 294 & 56.5 & $\begin{array}{l}\text { Primary } \\
\text { education }\end{array}$ & 53 & 10.2 \\
\hline \multirow[t]{2}{*}{ Female } & 226 & 43.5 & $\begin{array}{l}\text { Secondary } \\
\text { education }\end{array}$ & 341 & 65.6 \\
\hline & & & Diploma & 70 & 13.5 \\
\hline Ethnicity & & & Degree & 39 & 7.5 \\
\hline Malay & 142 & 27.3 & Others & 17 & 3.2 \\
\hline Iban & 72 & 13.8 & & & \\
\hline Bidayuh & 92 & 17.7 & Income level (RM) & & \\
\hline Chinese & 44 & 8.5 & Less than 500 & 42 & 8.1 \\
\hline Kelabit & 30 & 5.8 & $501-1000$ & 153 & 29.4 \\
\hline Penan & 29 & 5.6 & $1001-1500$ & 193 & 37.1 \\
\hline Berawan & 39 & 7.5 & $1501-2000$ & 36 & 6.9 \\
\hline \multirow[t]{2}{*}{ Others } & 72 & 13.8 & $2001-2500$ & 44 & 8.5 \\
\hline & & & $2501-3000$ & 6 & 1.2 \\
\hline $\begin{array}{l}\text { Marital } \\
\text { status }\end{array}$ & & & $3001-3500$ & 24 & 4.6 \\
\hline Single & 176 & 33.8 & 3501 and above & 22 & 4.2 \\
\hline Married & 333 & 64.1 & & & \\
\hline Others & 11 & 2.1 & & & \\
\hline \multicolumn{2}{|c|}{ Respondents $(N=520)$} & $M$ & SD & Minimum & Maximum \\
\hline \multicolumn{2}{|l|}{ Age (in years) } & 37 & 11.55 & 18 & 62 \\
\hline
\end{tabular}

\section{Statistical Analysis of the Measurement Model}

The SmartPLS 3.0 (M3) was used to analyse the confirmatory factor analysis. Confirmatory factor analysis was used to measure the loading and weight of an item, reliability, and validity. This was followed by convergent validity which consists of composite reliability and average variance extracted and discriminant validity.

A total of 22 reflective and 12 formative items was designed to measure the research model but the item PA09 was deleted for having a lower loading of 0.494. Table 2 shows the loading values achieved for the rural culture (0.782 - 0.875); cultural attractions $(0.761$ 0.871 ) and poverty alleviation (0.709 - 0.744) (Hair et al. 2010). The correlation of each item exceeded the recommended value of 0.5 . The tourism resources weight was between $(-0.081$ - 0.364). Therefore, the items are reliable and valid for the convergent validity test. 
Table 2: Result of the measurement model

\begin{tabular}{|c|c|c|c|c|c|}
\hline Variable & Item & Loading/Weight & $\begin{array}{c}\text { Composite } \\
\text { reliability }\end{array}$ & $\begin{array}{c}\text { Average } \\
\text { variance } \\
\text { extracte } \\
\text { d }\end{array}$ & Measure \\
\hline \multirow[t]{6}{*}{ Rural culture } & RC1 & 0.822 & 0.933 & 0.700 & Reflective \\
\hline & $\mathrm{RC2}$ & 0.875 & & & \\
\hline & $\mathrm{RC} 3$ & 0.843 & & & \\
\hline & $\mathrm{RC4}$ & 0.852 & & & \\
\hline & $\mathrm{RC5}$ & 0.841 & & & \\
\hline & $\mathrm{RC6}$ & 0.782 & & & \\
\hline \multirow[t]{7}{*}{ Cultural attractions } & CA1 & 0.813 & 0.937 & 0.680 & Reflective \\
\hline & CA2 & 0.871 & & & \\
\hline & CA3 & 0.862 & & & \\
\hline & CA4 & 0.836 & & & \\
\hline & CA5 & 0.795 & & & \\
\hline & CA6 & 0.829 & & & \\
\hline & CA7 & 0.761 & & & \\
\hline \multirow[t]{12}{*}{ Tourism resources } & TR1 & 0.340 & SIM & SIM & Formative \\
\hline & TR2 & 0.025 & & & \\
\hline & TR3 & 0.069 & & & \\
\hline & TR4 & -0.081 & & & \\
\hline & TR5 & 0.102 & & & \\
\hline & TR6 & 0.070 & & & \\
\hline & TR7 & 0.139 & & & \\
\hline & TR8 & 0.364 & & & \\
\hline & TR9 & 0.146 & & & \\
\hline & TR10 & 0.056 & & & \\
\hline & TR11 & 0.065 & & & \\
\hline & TR12 & 0.021 & & & \\
\hline \multirow[t]{8}{*}{ Poverty Alleviation } & PA01 & 0.733 & 0.900 & 0.529 & Reflective \\
\hline & PA02 & 0.709 & & & \\
\hline & PA03 & 0.735 & & & \\
\hline & PA04 & 0.744 & & & \\
\hline & PA05 & 0.736 & & & \\
\hline & PA06 & 0.714 & & & \\
\hline & PA07 & 0.724 & & & \\
\hline & PA08 & 0.721 & & & \\
\hline
\end{tabular}

Note: PA09 deleted due to low loading

As mentioned, convergent validity consists of composite reliability and average variance extracted tests. The composite reliability values were highly reliable for rural culture (0.933); cultural attractions (0.937) and poverty alleviation (0.900) as the threshold point was above 0.708 . The average variance extracted values for rural culture (0.700); cultural attractions (0.680) and poverty alleviation (0.529) were above the threshold value of 0.5 (Hair et al., 2014). Therefore, convergent validity was achieved in this study.

\section{Discriminant Validity}

Table 3 shows the comparison of the square root values of each variable. The average variance extracted values should be greater than other variables (Henseler \& Chin, 2010). The 
square root values of average variance extracted for rural culture (0.836), cultural attractions $(0.825)$ and poverty alleviation $(0.727)$ were greater than any other variable. Therefore, discriminant validity was achieved.

Table 3: Discriminant validity of measurement model

\begin{tabular}{lcccc}
\hline & CA & PA & RC & TR \\
\hline CA & $\mathbf{0 . 8 2 5}$ & & & \\
PA & 0.524 & $\mathbf{0 . 7 2 7}$ & & \\
RC & 0.699 & 0.501 & $\mathbf{0 . 8 3 6}$ & N/A \\
TR & 0.539 & 0.609 & 0.524 & \\
\hline
\end{tabular}

\section{Assessment of the Structural Model}

Figure 2 shows the positive t-value result of rural culture $(\mathrm{H} 1)$ and cultural attractions $(\mathrm{H} 2)$ on poverty alleviation. The tourism resources (moderator) $t$-value interaction result shows a stronger relationship between rural culture and poverty alleviation ( $\mathrm{H} 3)$ and a weaker relationship between cultural attractions and poverty alleviation $(\mathrm{H} 4)$.

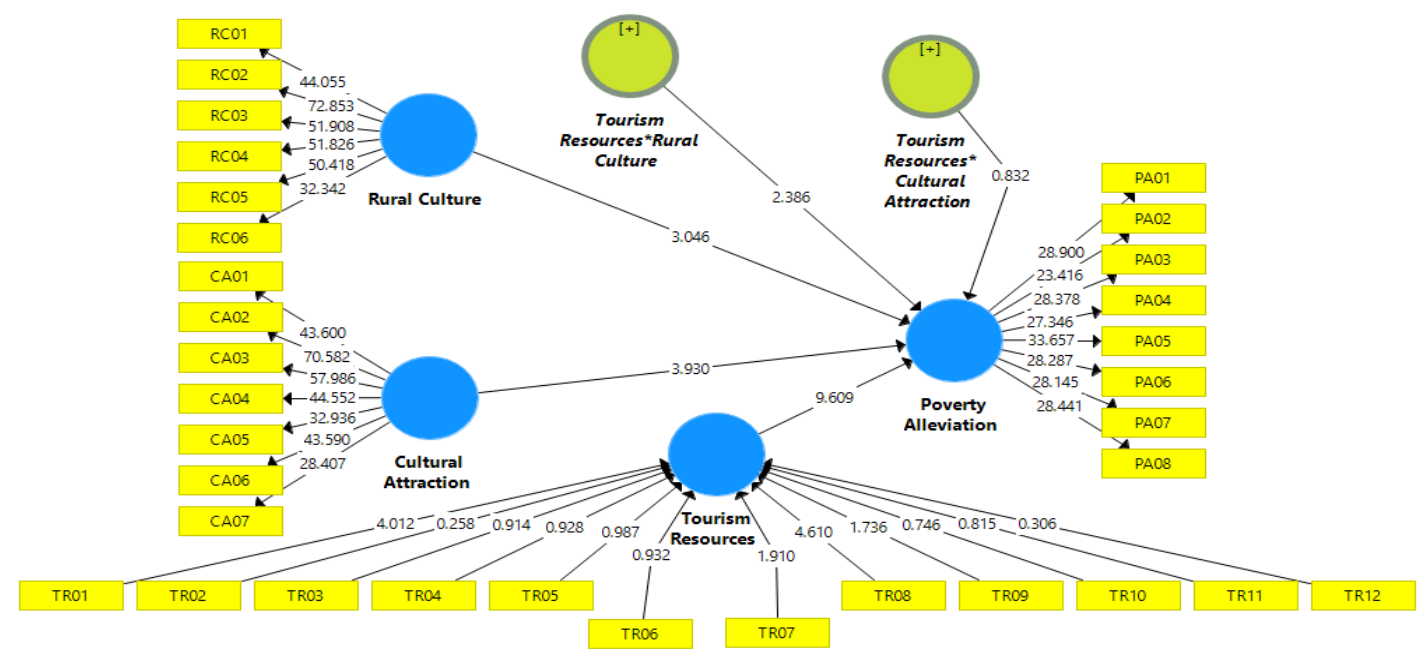

Figure 2: Results of structural model

Table 5: Path coefficients and hypothesis testing

\begin{tabular}{lcccc}
\hline Hypothesis & Relationship & Beta & t-value & Supported \\
\hline $\mathrm{H} 1$ & Rural culture $\rightarrow$ Poverty alleviation & 0.138 & $3.046^{* *}$ & Yes \\
\hline $\mathrm{H} 2$ & $\begin{array}{c}\text { Cultural attractions } \rightarrow \text { Poverty } \\
\text { alleviation }\end{array}$ & 0.196 & $3.930^{* *}$ & Yes \\
\hline $\mathrm{H} 3$ & $\begin{array}{c}\text { Rural culture*Tourism } \\
\text { resources } \rightarrow \text { Poverty alleviation }\end{array}$ & 0.129 & $2.386^{* *}$ & Yes \\
$\mathrm{H} 4$ & $\begin{array}{c}\text { Cultural attractions*Tourism } \\
\text { resources } \rightarrow \text { Poverty alleviation }\end{array}$ & -0.042 & 0.832 & No \\
\hline
\end{tabular}

Note: ${ }^{*} \mathrm{p}<0.05$, t-value greater than 1.645-2.32 (1 tailed)

$* * p<0.01$, t-value greater than 2.33 ( 1 tailed)

\section{Discussion}

H1: There is a positive relationship between rural culture and poverty alleviation.

Hypothesis 1 postulated a positive relationship between rural culture and poverty alleviation. Table 5 illustrates that the relationship between rural culture and poverty alleviation $(\beta=0.138$, $t$-value $=3.046)$ is positive, where the $t$-value is higher than $1.645(<0.05)$. The results 
appear to be in line with Agyeiwaah, Akyeampong and Amenumey (2013), Ahmad, Jabeen and Khan (2014), Salleh et al. (2016), and Le, Weaver and Lawton (2016) that rural culture alleviates poverty. The results also agree with the Human Development Theory which states that the promotion of rural culture in tourism engages the local communities to gain socioeconomic benefits. The local communities in this study are pleased to preserve their rural culture and traditions for the future generation. This creates an awareness among the younger generation in Sarawak on the importance of culture in generating income. The anxiety of losing their valuable heritage to modernisation explains why the local communities in Sarawak choose to preserve their rural culture. The preservation has also attracted the attention of tourists and United Nations Educational Scientific and Cultural Organisation to create cultural tourism. For example, the creation of Annah Rais Homestay in Kuching and collecting entrance fee to Annah Rais Homestay contributes to the Bidayuh tribe. The finding is supported by Grobar (2017) who confirmed that, in Peru, handicraft businesses preserve and promote rural culture. Furthermore, promoting rural culture to tourists breaks the isolation of the local communities and enables them to communicate with people from different countries to enhance their livelihood.

H2: There is a positive relationship between cultural attractions and poverty alleviation. Hypothesis 2 postulated a positive relationship between cultural attractions and poverty alleviation $(\beta=0.196$, $t$-value $=3.930$ ) (see Table 5 ). The finding is compatible with Ertugral and Dincer (2003), Aslam and Jolliffe (2015), and Vecco and Srakar (2017) who said that cultural attractions contribute to poverty alleviation. The finding is also consistent with the Human Development Theory which explains that cultural attractions in tourism improve the quality of life among the locals in Sarawak. For example, the Annah Rais Longhouse in Padawan is a unique tourist cultural attraction in Kuching. The Bidayuh community provides homestay facilities, works as tour guides, and sell their local harvest and souvenirs to tourists to generate income. Meanwhile, the entrance ticket charges are used to upgrade infrastructure facilities. The Sarawak Cultural Village and Annah Rais Longhouse are rich in cultural-historical and architectural monuments that make a treasury of the Sarawak culture for the next generation. The cultural attractions give a chance for all to visit. The aim of Sarawak Cultural Village and Annah Rais Longhouse is to attract a considerable number of domestic and foreign tourists to generate income. Likewise, in Kuching and Miri, the Gawai or Harvest Festival, Rainforest Music Festival, 'Nukenen' or Food and Cultural Festival, Siniawan (Chinese Village) Festival and Kaul Festival by the Melanau people are a few festivals celebrated to promote cultural attractions in generating income.

H3: Tourism resources moderates the relationship between rural culture and poverty alleviation.

Hypothesis 3 tested the moderating effect of tourism resources. Table 5 shows that tourism resources have a stronger relationship between rural culture and poverty alleviation $(\beta=0.129$, $t$-value $=2.386)$. The result is consistent with the Human Development Theory which describes that human's right in utilising resources to increase socio-economic development. Finding from this study show that utilising tourism resources such as culture, wildlife, nature, rural and physical alleviates poverty. The utilisation of tourism resources in a rural culture promotes permanent conservation and encourages sustainable management of Sarawak cultural heritage assets. Moreover, the use of tourism resources has helped in increasing the socio-economic level of a community and conserved the rural culture of Iban, Bidayuh, Kelabit, Penan, and Berawan. Vargas-Hernandez (2012), and Safiullin e al. (2014) said rural 
culture is a vital factor for socio-cultural and economic development in providing the use of tourism resources for livelihood sustainability is consistent with H3.

According to Figure 3, the relationship is positive at the high-level use of tourism resources but there is no relationship at the low-level use of tourism resources. The high-level use of tourism resources such as culture, wildlife, nature, rural and physical contributes to rural culture and poverty alleviation, as well as tourism resources utilised to produce cultural tourism, community-based tourism and gastronomy tourism to generate income. The low usage of tourism resources shows no relationship between rural culture and poverty alleviation. Therefore, a high-level use of tourism resources is recommended for poverty alleviation in tourism development.

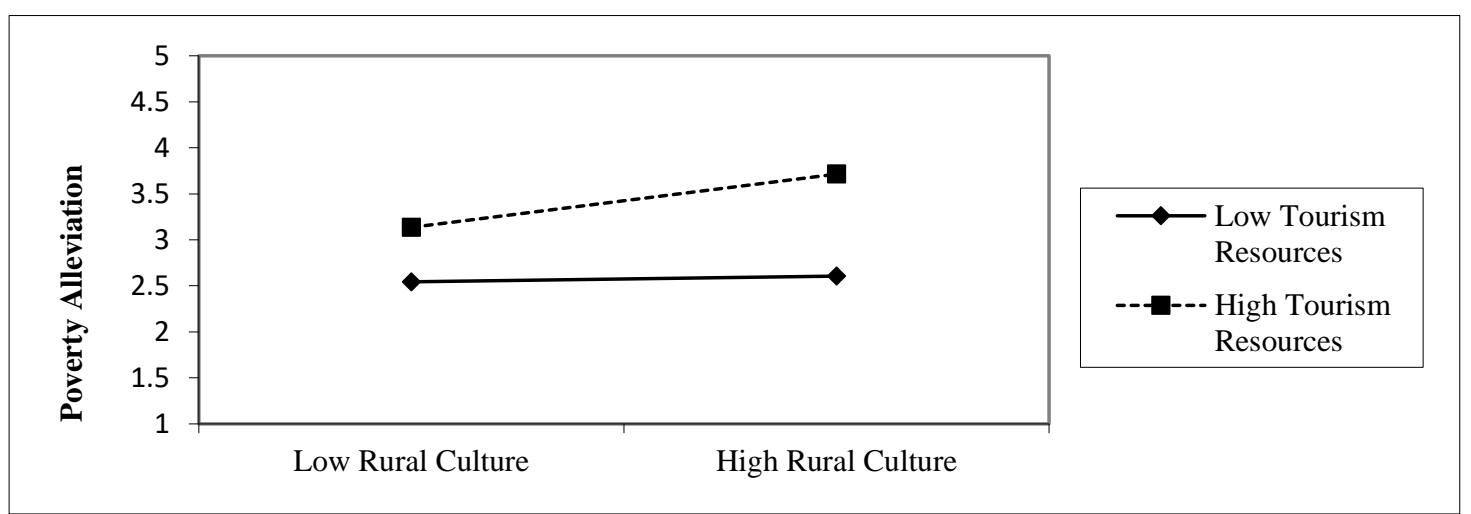

Figure 3: The effect of interaction on rural culture and tourism resources on poverty alleviation

H4: Tourism resources moderate the relationship between cultural attractions and poverty alleviation

Hypothesis 4 tested tourism resources effect between cultural attractions and poverty alleviation. The results reveal that tourism resources have a weak relationship between cultural attractions and poverty alleviation $(\beta=-0.042$, t-value $=0.832)$ (see Table 5$)$. The results seem to contradict past studies such as Daskon and Binns (2010); Petersen and Pedersen (2010) and Smith and Ram (2017) who view tourism resources as a resource to generate income. A lack of community commitment, influence of the power of authorities, economic circumstances, and levels of modernisation probably have led to this insignificant result. Therefore, engaging and managing tourism resources wisely in tourism helps in alleviating poverty.

The highest number of respondents ( 86 / 16.5\%) work as accommodation providers while the lowest number of respondents were handicraft, pottery and edible local product producer (28 / 5.4\%) and souvenir sellers (26/5.0\%). Refering to Table $4_{L}$ the result show that the larger tourism businesses gained more revenue than local communities. Therefore, promoting cultural resources such as festivals, traditions, heritage, and celebrations in rural areas may benefit the locals directly. Implementing a policy to export Sarawak handicrafts worldwide by the Ministry of Tourism, Arts, and Culture Sarawak may contribute to the community directly as what has been proven in Peru (Grobar 2017). 
Table 4: Tourism Related Jobs of the Respondents

\begin{tabular}{lcc}
\hline & \multicolumn{2}{c}{ Respondents $(N=520)$} \\
\hline Tourism Job Specialisation & Frequency $(n)$ & Percentage (\%) \\
\hline Tour guide & 42 & 8.1 \\
Accommodation provider (i.e., homestay, hotel, resort, or bed & 86 & 16.5 \\
and breakfast) & & \\
Food and beverage provider & 75 & 14.4 \\
Transport provider & 43 & 8.3 \\
Travel operator (i.e., travel agency and information centre) & 63 & 12.1 \\
Tourism event and cultural activity organiser & 45 & 8.6 \\
Souvenir seller & 26 & 5.0 \\
Handicraft, pottery or edible local product producer & 28 & 5.4 \\
Nature conservation and wildlife, bat and bird protector & 30 & 5.8 \\
Tourism management department & 50 & 9.6 \\
Other tourism jobs (i.e., security, maintenance, gardener) & 32 & 6.2 \\
\hline
\end{tabular}

\section{Multicollinearity (VIF)}

Table 6 indicates that multicollinearity did not exist among the exogenous variables as all variance inflation factor (VIF) values are under or less than 3.3 (Diamantopoulos and Sigouw 2006). Therefore, there were no multicollinearity issues between the constructs in the structural model.

Table 6: Variance Inflation Factors (VIF)

\begin{tabular}{lc}
\hline Exogenous Construct & VIF \\
\hline Rural Culture & 2.272 \\
Cultural Attractions & 2.612 \\
Tourism Resources & 2.719 \\
\hline
\end{tabular}

Note: Variance Inflation Factors (VIF) should be under or less than $<3.3$

\section{Coefficient of Determination $\left(\mathbf{R}^{2}\right)$ of the Moderating Effects}

The $R^{2}$ value is used to measure the strength of the moderating effects of tourism resources on the conceptual framework in this study. Table 7 indicates the model predicted accuracy increased from 0.435 to 0.447 with tourism resources. The rule of thumb for the acceptable $R^{2}$ is 0.67 (substantial), 0.33 (moderate) and 0.19 (weak) (Chin, 2010). Thus, the framework strength was at a moderate level and can be considered acceptable.

Table 7: $\mathrm{R}^{2}$ on poverty alleviation with and without interaction effect

\begin{tabular}{lcc}
\hline Endogenous Construct & \multicolumn{2}{c}{$\mathbf{R}^{2}$ Variance } \\
\cline { 2 - 3 } & $\begin{array}{c}\text { Without Interaction } \\
\text { Effect }\end{array}$ & With Interaction Effect \\
\hline Poverty Alleviation & 0.435 & 0.447 \\
\hline
\end{tabular}

\section{Conclusions}

The aim of this study is to examine the impact of rural culture and cultural attractions on poverty alleviation and the moderator effect of tourism resources between rural culture and cultural attractions in alleviating poverty. The findings show permanent conservation and sustainable use of tourism resources such as cultural buildings, monuments, cultural landscapes, traditional arts, crafts, food, and customs can promote socio-economic development. The finding of this study can become the avenue of future studies to focus on certain ethnic groups Sarawak on cultural tourism in alleviating poverty with the use of 
tourism resources. Besides, a case study involving one ethnic group might explain cultural tourism in a specific context. The local communities are concerned about preserving their rural cultures and cultural attractions. Hence, studying rural cultures and cultural attractions of specific ethnic groups may create awareness among the younger generation about the importance of cultural protection as well as differences between cultures, beliefs and customs.

Acknowledgement: This work was supported by Universiti Malaysia Sarawak [grant numbers S01/SpSTG/1397/16/39]

\section{References}

Agyeiwaah, E., Akyeampong, O., \& Amenumey, E.K. (2013). International tourists' motivations to choose homestay: Do their socio-demographics have any influence? Tourism and Hospitality Research 13(1): 16-26.

Ahmad, S. Z., Jabeen, F., \& Khan, M. (2014). Entrepreneurs choice in business venture: Motivations for choosing homestay accommodation businesses in Peninsular Malaysia. International Journal of Hospitality Management 36: 31-40.

Aslam, M. S. M., \& Jolliffe, L. (2015). Repurposing colonial tea heritage through historic lodging. Journal of Heritage Tourism 10(2): 111-128.

Baron, R. M., \& Kenny, D.A. (1986). The moderator mediator variable distinction in social psychological research: Conceptual, strategic, and statistical considerations. Journal of Personality and Social Psychology 51(6): 1173-1182.

Bruner, G. C., \& Hensel, P.J. (1993). Multi-item scale usage in marketing journals: 1980 to 1989. Journal of the Academy of Marketing Science 21(4): 339-344.

Butler, R., \& Hinch, T. (2007). Tourism and Indigenous Peoples: Issues and Implications. England: Elsevier.

Cetin, G., \& Bilgihan, A. (2016). Components of cultural tourists' experiences in destinations. Current Issues in Tourism 19(2): 137-154.

Chin, C. H. (2015). Rural tourism destination competitiveness: The moderating impact of commnity support. Master's diss., Institute of Social Informatics and Technological Innovations (ISITI), University Malaysia Sarawak.

Chin, W. W. (2010). How to write up and report PLS analyses. In Handbook of Partial Least Squares, eds. V. V. Esposito, W. W. Chin, J. Henseler and H. Wang, 655-690. Springer: Berlin.

Daskon, C., \& Binns, T. (2010). Culture, tradition and sustainable rural livelihoods: Exploring the culture-development interface in Kandy, Sri Lanka. Community Development Journal 45(4): 494-517.

Derrett, R. (2004). Festivals, events and the destination. In Festival and Events Management: An International Arts and Culture Perspectiv, ed. I. Yeoman, 32-64. London: Routledge.

Diamantopoulos, A., \& Siguaw, J. A. (2006). Formative versus reflective indicators in organizational measure development: A comparison and empirical illustration. Journal of Management 17(4): 263-282.

Dong, T. B. (2020). Cultural Tourism: An Ethnographic Study of Home stay in Briddim Village, Nepal. The Gaze: Journal of Tourism and Hospitality 11(1): 10-36.

Duffield, B. S. (1982). Tourism: The measurement of economic and social impact. Tourism Management 3(4): 248-255.

Economic Planning Unit. (2006). Ninth Malaysia Plan. 2006-2010. Economic Planning Unit. 
Ertugral, S. M., \& Dincer, F. I. (2003). Economic impact of heritage tourism hotels in Istanbul. Journal of Tourism Studies 14(2): 23-34.

Faulkner, B., \& Tideswell, C. (1997). A framework for monitoring community impacts of tourism. Journal of Sustainable Tourism 5(1): 3-28.

Frost, W., \& Laing, J. (2013). Communicating persuasive messages through slow food festivals. Journal of Vacation Marketing 19(1): 67-74.

Gray, M. (2004). Geodiversity: Valuing and Conserving Abiotic Nature. England: John Wiley and Sons.

Gholami, S., Assayesh, H., \& Alipour-Nakhi, A. (2010). The study of tourism geography in rural areas of Noushahr City of Mazandaran Province (Iran): The case of Balade Kojour Vill. American Eurasian Journal of Agricultural and Environmental Science 7(3): 341-346.

Grobar, L. M. (2017). Policies to promote employment and preserve cultural heritage in the handicraft sector. International Journal of Cultural Policy 13: 1-13.

Hair, J. F., Anderson, R.E., Babin, B. J. \& Black, W.C. (2010). Multivariate Data Analysis: A Global Perspective. New Jersey: Pearson.

Hair, J. F., Hult, G. T. M., Ringle, C., \& Sarstedt, M. (2014). A primer on partial least squares structural equation modeling (PLS-SEM). Los Angeles: Sage Publications.

Hair, J. F., Ringle, C. M., \& Sarstedt, M. (2011). PLS-SEM: Indeed a silver bullet. Journal of Marketing theory and Practice 19(2): 139-152.

Hall, C. M., \& Macionis, N. (1998). Wine tourism in Australia and New Zealand. In Tourism and Recreation in Rural Areas, eds. R. Butler, C. M. Hall and J. M. Jenkins, 267-298. John Wiley \& Sons: Chichester.

Henseler, J., \& Chin, W. W. (2010). A Comparison of Approaches for the Analysis of Interaction Effects Between Latent Variables Using Partial Least Squares Path Modeling. Structural Equation Modeling: A Multidisciplinary Journal 17(1): 82-109.

Hillman, P., Moyle, B. D., \& Weiler, B. (2017). Perceptions of impacts and development in a cultural tourism hub: Ubud, Bali. In Balancing Development and Sustainability in Tourism Destinations, eds. A. Saufi, I. Andilolo, N. Othman and A. Lew, 57-66. Springer: Singapore.

Israel, G. D. (1992). Sampling the evidence of extension program impact. University of Florida: Institute of Food and Agriculture Sciences

Kennedy, K., \& Dornan, D. A. (2009). An overview: Tourism non-governmental organizations and poverty reduction in developing countries. Asia Pacific Journal of Tourism Research 14(2): 183-200.

Keovilay, T. (2012). Tourism and Development in Rural Communities: A Case Study of Luang Namtha Province Lao PDR. Master's diss., Department of Tourism Sport and Society, Lincoln University, New Zealand.

Kiernan, K. (2013). The nature conservation, geotourism and poverty reduction nexus in developing countries: A case study from the Lao PDR. Geoheritage 5(3): 207-225.

Khazanah Research Institute. (2018). The State of Households: Different Realities. Kuala Lumpur: Perpustakaan Negara Malaysia.

Le, T. A., Weaver, D., \& Lawton., L. (2016). Community based tourism and development in the periphery or semi periphery interface: A case study from Vietnam. In Reframing Sustainable Tourism, eds. F. Stephen, F. McCool and K. Bosak, 161-181. Springer: Amsterdam. 
Llorca-Rodríguez, C. M., García-Fernández, R. M., \& Casas-Jurado, A. C. (2020). Domestic versus inbound tourism in poverty reduction: Evidence from panel data. Current Issues in Tourism 23(2): 197-216.

Lo, M. C., Ramayah, T., \& Hui, H. L. H. (2014). Rural communities perceptions and attitudes towards environment tourism development. Journal of Sustainable Development 7(4): 84-94.

Lucchetti, V. G., \& Font, X. (2013). Community-based tourism: Critical success factors. The Internafional Centre for Responsible Tourism 27(1): 1-20.

Manwa, H., \& Manwa, F. (2014). Poverty alleviation through pro-poor tourism: The role of Botswana forest reserves. Sustainability 6(9): 5697-5713.

McClinchey, K. A., \& Carmichael, B. A. (2010). Countryside capital, changing rural landscapes and rural tourism implications in Mennonite Country. Journal of Rural and Community Development 5(1): 179-199.

Ministry of Tourism, Arts, and Culture Sarawak. (2016). Sarawak Tourism Quick Facts 2016. http://www.mtacys.sarawak.gov.my/upload/file_folder/Tourism \%20Sarawak Quick\%20Facts\%202016.pdf (accessed: 21 November 2017).

Mitchell, J., \& Ashley, C. (2010). Tourism and Poverty Reduction: Pathways to Prosperity. London: Earthscan.

Miyakuni, K. (2012). Residents' Attitudes Toward Tourism, Focusing on Ecocecentric Attitudes and Perceptions of Economic Costs: The case of Iriomote Island, Japan. PhD diss., Park, Recreation and Tourism Resources, Michigam State University.

Mohamed, A. M. E. (2013). Actor-Network Theory, Tourism Organisations and the Development of Sustainable Community Livelihoods. PhD diss., Plymouth Business School, University of Plymouth.

Moorhouse, T., d'Cruze, N. C., \& Macdonald, D. W. (2017). Unethical use of wildlife in tourism: What's the problem, who is responsible and what can be done? Journal of Sustainable Tourism 25(4): 505-516.

Mostafanezhad, M. (2014). Volunteer tourism and the popular humanitarian gaze. Geoforum 54: 111-118.

Mthembu, B. M. J. (2011). Rural Tourism as a Mechanism for Poverty Alleviation in KwazuluNatal: The case of Bergville. PhD diss., Graduate School of Business and Leadership, University of KwaZulu-Natal.

Muhanna, E. (2007). Tourism Development Strategies and Poverty Elimination. Problems and Perspectives in Management 5(1): 37-49.

Musinguzi, D. (2012). The impacts of tourism on local communities: Developing and operationalising a comprehensive monitoring framework. PhD diss., School of Hotel and Tourism Management, The Hong Kong Polytechnic University.

Njoya, E. T., \& Seetaram, N. (2018). Tourism contribution to poverty alleviation in Kenya: A dynamic computable general equilibrium analysis. Journal of travel research 57(4): 513524.

Nitikasetsoontorn, S. (2014). The Success Factors of Community Based Tourism in Thailand. PhD diss., School of Public Administration, National Institute of Development Administration, Bangkok.

Notzke, C. (2016). Wild horse-based tourism as wildlife tourism: The wild horse as the other. Current Issues in Tourism 19(12): 1235-1259.

Okumus, F., Avci, U., Kilic, I., \& Walls, A. R. (2012). Cultural tourism in Turkey: A missed opportunity. Journal of Hospitality Marketing and Management 21(6), 638-658. 
Pawson, S., d'Arcy, P., \& Richardson, S. (2015). The value of community-based tourism in Banteay Chhmar, Cambodia. Tourism Geographies 19(3): 378-397.

Petersen, E. K., \& Pedersen, M. L. (2010). The sustainable livelihoods approach. Aquaculture Economics Management 13(1):1-27.

Rattan, J. K., Eagles, P. F. J. (2012). Volunteer tourism: Its role in creating conservation awareness. Journal of Ecotourism 11(1): 1-15.

Reisinger, Y., \& Steiner, C. J. (2006). Reconceptualizing object authenticity. Annals of Tourism Research 33(1): 65-86.

Richards, G. (2001). The Development of Cultural Tourism in Europe. Cultural Attractions and European Tourism. Oxon: Cabi.

Saarinen, J. (2010). Local tourism awareness: community views in Katutura and King Nehale conservancy Namibia. Development Southern Africa 27(5): 713-724.

Saarinen, J., \& Rogerson, C. M. (2014). Tourism and the millennium development goals: Perspectives beyond 2015. Tourism Geographies 16(1): 23-30.

Saayman, M., Rossouw, R., \& Krugell, W. (2012). The impact of tourism on poverty in South Africa. Development Southern Africa 29(3): 462-487.

Safiullin, L. N., Gafurov, I. R., Shaidullin, R. N., \& Safiullin, N. Z. (2014). Socio-economic development of the region and its historical and cultural heritage. Life Science Journal 11(6): 400-404.

Salazar, N. (2012). Community-based cultural tourism: Issues, threats and opportunities. Journal of Sustainable Tourism 20(1): 9-22.

Salleh, N. H. M., Shukor, M. S., Othman, R., Samsudin, M., \& Idris, S. H. M. (2016). Factors of Local Community Participation in Tourism-Related Business: Case of Langkawi Island. International Journal of Social Science and Humanity 6(8): 565-571.

Satarat, N. (2010). Sustainable Management of Community-Based Tourism in Thailand. PhD diss., School of Public Administration, National Institute of Development Administration, Bangkok.

Sathkumara, S. M. P. D. (2014). An Examination of Preparedness of Community for Community Based Tourism Sri Lanka: A Case Study of Kalpitiya Tourism Area. PhD diss., Department of Town and Country Planning, University of Moratuwa.

Sekaran, U. (2003). Research Methods for Business: A Skill Building Approach. New York: John Wiley and Sons.

Sen, G. (1999). Engendering poverty alleviation: Challenges and opportunities. Development and Change 30(3): 685-692.

Sharpley, R., \& Harrison, D. (2019). Introduction: tourism and development-towards a research agenda: A Research Agenda for Tourism and Development. United Kingdom: Edward Elgar.

Sharpley, R., \& Telfer, D. J. (2014). Tourism and Development: Concepts and Issues. Bristol: Channel View Publications.

Smith, M., \& Ram, Y. (2017). Tourism, landscapes and cultural ecosystem services: A new research tool. Tourism Recreation Research 42(1): 113-119.

Spenceley, A., Habyalimana, S., Tusabe, R., \& Mariza, D. (2010). Benefits to the poor from gorilla tourism in Rwanda. Development Southern Africa 27(5): 647-662.

Suntikul, W., \& Dorji, U. (2016). Local perspectives on the impact of tourism on religious festivals in Bhutan. Asia Pacific Journal of Tourism Research 21(7): 741-762. 
Suntikul, W., Pratt, S. I., Kuan, W., Wong, C. I., Chan, C. C., Choi, W. L., \& Chong, O. F. (2016). Impacts of tourism on the quality of life of local residents in Hue, Vietnam. Anatolia 27(4): 405-420.

Truong, V. D. (2014). Tourism and poverty alleviation: A case study of Sapa, Vietnam. PhD diss., Department of Management, Marketing and Entrepreneurship, University of Canterbury.

United Nations World Tourism Organisation. (2017). Tourism Highlights 2017 Edition. https://www.e-unwto.org/doi/pdf/10.18111/9789284419029 (Accessed: 2 September 2018)

Vargas-Hernandez, J. G. (2012). Sustainable cultural and heritage tourism in regional development of Southern Jalisco. World Journal of Entrepreneurship, Management and Sustainable Development 8(2): 146-161.

Vecco, M., \& Srakar, A. (2017). Blue notes: Slovenian jazz festivals and their contribution to the economic resilience of the host cities. European Planning Studies 25(1): 107-126.

World Bank. (2016). Understanding Poverty. Retrieved from: http://www.worldbank.org/en/topic/poverty/overview (Accessed: 28 December 2017)

Welzel, C., Inglehart, R., \& Klingemann, H. D. (2003). Human development as a theory of social change: A cross-cultural perspective. European Journal of Political Science 42(3): 341379.

Yamane, T. (1967). Statistics: An Introductory Analysis. New York: Harper and Row.

Yoon, Y., Gursoy, D., \& Chen, J. S. (2001). Validating a tourism development theory with structural equation modelling. Tourism Management 22(4): 363-372.

Yung, E. H. K., \& Chan, E. H. W. (2012). Critical social sustainability factors in urban conservation: The case of the central police station compound in Hong Kong. Facilities 30(9): 396-416.

Zyl, V. I., Inversini, A., \& Rega, I. (2015). The representation of voluntourism in search engines: The case of South Africa. Development Southern Africa 32(3): 333-349. 